\title{
Complete Response of Multiple Myeloma or Plasma Cell Leukemia
}

National Cancer Institute

\section{Source}

National Cancer Institute. Complete Response of Multiple Myeloma or Plasma Cell

Leukemia. NCI Thesaurus. Code C70639.

Complete response of multiple myeloma or plasma cell leukemia is characterized by negative immunofixation on serum and urine samples, and disappearance of any soft tissue plasmacytomas, and less than 5\% plasma cells in the bone marrow (confirmation with repeat bone marrow biopsy not needed). Complete response requires two consecutive assessments made at any time before the institution of any new therapy, and no known evidence of progressive or new bone lesions if radiographic studies were performed; radiog raphic studies are not required to satisfy complete response requirements. 